\title{
Seria wydawnicza: Żydzi. Polska. Autobiografia realizowana w ramach projektu „Kanon literatury wspomnieniowej Żydów polskich" przez Katedrę Judaistyki im. Tadeusza Taubego na Uniwersytecie Wrocławskim ${ }^{1}$
}

\begin{abstract}
$\mathrm{Z}$ ajmując się badaniami dziejów Żydów w XIX i XX w. oraz prowadząc zajęcia ze studentami i doktorantami poświęcone tej tematyce, niejednokrotnie napotykam na spore trudności w dotarciu do egodokumentów osób pochodzenia żydowskiego, prezentujących żydowską perspektywę minionej rzeczywistości. Wykorzystywanie takich autobiografii, zarówno w pracy naukowej, jak i podczas zajęć dydaktycznych ze studentami czy młodzieżą szkolną, jest tym bardziej ważne i potrzebne, że jako źródła o charakterze opisowym, narracyjnym, doskonale oddają one specyfikę żydowskiego życia. Z perspektywy jednostki pozwalają na dotarcie do informacji, które są wręcz niedostępne w źródłach o charakterze aktowym i dokumentowym. Pozwalają przyjrzeć się bliżej wielu kwestiom dotąd w ogóle nieznanym lub wręcz odmiennie przedstawianym w dostępnych opracowaniach w języku polskim.

W rezultacie, publikowanie od roku 2018 kolejnych tomów egodokumentów w ramach serii wydawniczej: Żydzi. Polska. Autobiografia wychodzi naprzeciw oczekiwaniom nie tylko naukowców i studentów, ale całego, sporego już w Polsce środowiska osób zainteresowanych historią i kulturą Żydów. Pozwolę sobie w tym kontekście także zaryzykować stwierdzenie, że szeroki dostęp do zawartej w wydawanych autobiografiach źródłowej wiedzy na temat problemów nurtujących społeczności żydowskie zamieszkujące ziemie polskie będzie miał wręcz przełomowe znaczenie w dotychczasowym postrzeganiu przez Polaków dawnego żydowskiego świata, charakteryzującego się dużą hermetycznością, czy też relacji Żydów z innymi grupami narodowymi oraz religijnymi.

Od lat śledzę z uwagą i podziwem bardzo dynamiczny rozwój judaistyki na Uniwersytecie Wrocławskim. Należy z uznaniem odnieść się do starań ludzi związanych z Katedrą Judaistyki na tym Uniwersytecie, którzy podjęli tę potrzebną, a zarazem bardzo rozległą w swym zakresie oraz trudną do realizacji inicjatywę naukową i wydawniczą. Kierownikiem projektu pn. „Kanon literatury wspomnieniowej Żydów polskich" jest prof. dr hab. Marcin Wodziński, zarazem kierownik Katedry Judaistyki, a redaktorem serii wydawniczej Żydzi. Polska. Autobiografia - dr hab. Joanna Lisek, pracownica tej Katedry. Zasadność tego ważnego przedsięwzięcia jego inicjatorzy trafnie uzasadniają w następujący sposób:
\end{abstract}

„[...] Ze względu na [...] wielowiekową wspólną historię żydowska literatura powstała na ziemiach polskich zasługuje na traktowanie jej jako ważnej czę-

1 Realizacja tego projektu, finansowanego przez Ministerstwo Nauki i Szkolnictwa Wyższego w ramach Narodowego Programu Rozwoju Humanistyki, odbywa się we współpracy z Muzeum Historii Żydów Polskich POLIN. 
ści heterogenicznie rozumianego dziedzictwa narodowego Polski. Literatura dokumentu osobistego pozostaje szczególnie istotnym elementem tego dziedzictwa, ponieważ stanowi medium pomiędzy historią a pamięcią, pomiędzy doświadczeniem zbiorowym a losem jednostkowym. Rozumienie polskiej kultury narodowej bez uwzględnienia tego ważnego korpusu tekstów jest po prostu niepełne. [...]

Celem tego interdyscyplinarnego projektu jest udostępnienie w polskim przekładzie kanonu żydowskiej literatury wspomnieniowej jako jednego z niezwykle ważnych, a niemal nieznanych źródeł do dziejów społecznych i dziejów kultury, obyczaju, religii ziem polskich. Choć literatura egodokumentu to jedno z najważniejszych źródeł w interdyscyplinarnych badaniach historyczno-społecznych, kulturowych czy literaturoznawczych, żydowska literatura wspomnieniowa z ziem polskich (definiowanych tu jako obszar dawnej Rzeczypospolitej Obojga Narodów) jest niemal nieznana polskiemu czytelnikowi, i to nie tylko w kręgach popularnych, ale również badaczom przeszłości Polski. Dzieje się tak ze względu na słabą dostępność niektórych z ważnych tekstów wspomnieniowych Żydów polskich, ale przede wszystkim ze względu na barierę językową. [...]

Zadaniem serii tłumaczeń najważniejszych tekstów literatury wspomnieniowej Żydów polskich jest wprowadzenie tych niezwykle istotnych źródeł do polskiego obiegu naukowego i literackiego oraz zintegrowanie tego korpusu z obecną wiedzą na temat historii i kultury Polski. [...]

Teksty te będą zapewne bezcennym źródłem w pracach badawczych polskich historyków, kulturoznawców, filologów, socjologów, stworzą również kanoniczny zasób źródłowy dla coraz żywiej rozwijających się w Polsce studiów żydowskich. Ponadto, seria będzie mogła być wykorzystywana w szeroko rozumianej edukacji humanistycznej, na różnych jej poziomach, a wiele tekstów atrakcyjnych literacko wzbogaci polski obieg literacki"2.

Inicjatorzy tego ambitnego przedsięwzięcia przewidują opublikowanie 27 krytycznie opracowanych tomów, stanowiących tłumaczenia najważniejszych tekstów literatury wspomnieniowej polskich Żydów ${ }^{3}$. Zajmujący się tym zespół liczy trzydziestu tłumaczy i redaktorów, zarówno z Wrocławia, jak i z innych ośrodków akademickich. Opublikowane i przygotowywane do druku wspomnienia tłumaczone są z języka hebrajskiego, jidysz, niemieckiego, rosyjskiego. Będą to również egodokumenty powstałe w języku polskim, dotąd nieopublikowane. Seria wydawnicza Żydzi. Polska. Autobiografia obejmuje teksty powstałe od początku wieku XVII aż do połowy XX. Ich autorami są Żydzi i Żydówki, praktycznie z wszystkich ziem dawnej Rzeczypospolitej - z Wielkopolski, centralnej Polski, Wołynia, Galicji, Polesia, Podola, jak również Białorusi, Litwy i Ukrainy. Poszczególni autorzy reprezentują różne nurty judaizmu, opcje kulturowe czy polityczne preferencje ${ }^{4}$. Są to zarówno osoby znane, cieszące się sławą, jak i takie,

2 Kanon literatury wspomnieniowej Żydów polskich. Katedra Judaistyki Uniwersytetu Wrocławskiego - zob.: http://zydzi.autobiografia.uni.wroc.pl/ [dostęp: 16.11.2021].

3 Ibidem.

4 Żydzi. Polska. Autobiografia - zob.: https://judaistyka.uni.wroc.pl/dla-studentow/ [dostęp: 16.11.2021]. 
o których dowiadujemy się po raz pierwszy, charakteryzujące się różnym stopniem wykształcenia, mieszkające w wielkich miastach oraz w małych miasteczkach ${ }^{5}$.

Każdy z dostępnych już w sprzedaży tomów - starannie wydanych, co z uznaniem należy podkreślić - jest wnikliwie przetłumaczony na język polski i bardzo dobrze opracowany krytycznie pod względem naukowym. Poza właściwym tekstem wspomnień, opatrzonym licznymi, a niejednokrotnie także dość obszernymi przypisami, znajduje się tu naukowy wstęp, opracowany z dużym znawstwem zagadnień poruszanych we wspomnieniach. Ponadto każdy tom ma notę edytorską, bibliografię umożliwiającą poszerzenie wiedzy o poruszanej w danych wspomnieniach tematyce, streszczenie w języku angielskim, spis ilustracji i indeks, znacznie ułatwiający lekturę.

Dotychczas ukazało się osiem tomów serii. W 2018 r. opublikowano wspomnienia Ludwiga Kalischa ${ }^{6}$ i pierwszy tom wspomnień Jecheskiela Kotlika ${ }^{7}$. Urodzony w Lesznie w 1814 r., mający żydowskie pochodzenie Ludwig Kalisch był cenionym niemieckim dziennikarzem i eseistą, co również znajduje odzwierciedlenie w jego wspomnieniach. Natomiast urodzony w 1847 r. Jecheskiel Kotlik odnosi się w pierwszym tomie swoich wspomnień do dziecięcych i młodzieńczych lat spędzonych w Kamieńcu Litewskim. Talent literacki, jakim się wykazał, przyniósł mu, po opublikowaniu tego tomu wspomnień w języku jidysz w Warszawie w 1912 r., uznanie nawet Szolem Alejchema, czołowego żydowskiego pisarza XX wieku.

Następnie wydano w 2019 r. Najstarsze pamiętniki Żydów krakowskich ${ }^{8}$ i drugi tom wspomnień Jecheskiela Kotlika9 . Najstarsze pamiętniki Żydów krakowskich zawierają wspomnienia urodzonego na Morawach w 1594 lub 1595 r. Meir ben Jechiel Kadosza, zatytułowane Zwój pana Meira oraz wspomnienia jednego z najwybitniejszych rabinów Europy Środkowo-Wschodniej, wybranego w 1643 r. rabinem Krakowa Jom Tow Lipmanna Hellera, pod tytułem Zwój nienawiści. Obydwa teksty to najstarsze pamiętniki Żydów krakowskich. Natomiast drugi tom wspomnień Jecheskiela Kotlika odnosi się do realiów miast i miasteczek, w których przebywał, szukając dla siebie godnego zajęcia, zlokalizowanych w strefie osiedlenia.

Kolejne dwa interesujące tomy tej serii żydowskiej literatury autobiograficznej opublikowano w 2020 r. Ich autorami są Estera Rachela Kamińska ${ }^{10}$ i Mordechaj Aron Gincburg ${ }^{11}$. Jak wiadomo, urodzona w 1870 r. Estera Rachela Kamińska uznawana

5 J. Lisek, Żydowskie egodokumenty w serii „Żydzi. Polska. Autobiografia”, „Studia Judaica” 2020, nr 2(46), s. 377.

6 L. Kalisch, Obrazki z moich lat chłopięcych, wstęp, oprac. i tłumaczenie z niemieckiego M. Błaszkowski, Wydawnictwo PWN, Warszawa 2018.

7 J. Kotik, Moje wspomnienia, t. I, wstęp i oprac. D. Assaf, tłumaczenie z języków angielskiego i jidysz A. Reibach, Wydawnictwo PWN, Warszawa 2018.

8 Meir ben Jechiel Kadosz z Brodu, Zwój pana Meira, wstęp, tłumaczenie z języka hebrajskiego i oprac. L. Kwiatkowski; Jom Tow Lipmann Heller, Zwój nienawiści, wstęp, tłumaczenie z języka hebrajskiego i oprac. A. Paluch, [w:] Najstarsze pamiętniki Żydów krakowskich, wprowadzenie A. Paluch, L. Kwiatkowski, Wydawnictwo PWN, Warszawa 2019.

9 J. Kotik, Moje wspomnienia, t. II, tłumaczenie z języka jidysz i oprac. A. Reibach, Wydawnictwo PWN, Warszawa 2019.

10 E.R. Kamińska, Boso przez ciernie i kwiaty. Memuary „matki teatru żydowskiego”, wstęp, tłumaczenie z języka jidysz i oprac. M.M. Bałut, Wydawnictwo PWN, Warszawa 2020.

11 M.A. Gincburg, Awiezer. Wyznania maskila, wstęp, tłumaczenie z języka hebrajskiego i oprac. A. Piątek, Wydawnictwo PWN, Warszawa 2020. 
jest za „matkę teatru żydowskiego”. W swych wspomnieniach opisuje bardzo barwnie koleje swego losu, od czasów dzieciństwa aż do okresu, gdy była już znaną i cenioną aktorką. Natomiast urodzony w 1795 r. pisarz, tłumacz oraz pedagog Mordechaj Aron Gincburg był maskilem, zwolennikiem haskali, czyli żydowskiego oświecenia, co starał się bardzo obszernie uzasadnić w swoich wspomnieniach.

Zgodnie z dotychczasową praktyką, wynikającą z harmonogramu prac określonych w realizowanym projekcie, w 2021 r. wydano tomy autorstwa Beniamina R. ${ }^{12}$ i Racheli Fajgenberg ${ }^{13}$. Beniamin r. to najprawdopodobniej urodzony w Bielsku Podlaskim w 1916 r. Beniamin (Samuel, Boszke) Brawerman, pochodzący z ubożejącej rodziny kupieckiej. Jego wspomnienia dotyczą głównie lat trzydziestych XX w. Przenoszą nas w świat żydowskich ugrupowań politycznych, w które angażowała się żydowska młodzież. Ukazują także zjawiska przemocy antyżydowskiej. Zjawiska te można dostrzec również w innych omawianych tomach, a w największym stopniu we wspomnianym już tekście Meir ben Jechiel Kadosza Zwój pana Meira. Kolejna autorka, pochodząca z rabinackiej rodziny Rachela Fajgenberg, urodziła się w 1885 r. w Lubaniu, na terenie obecnej Białorusi. Była pisarką tworzącą w językach jidysz i hebrajskim. W okresie II Rzeczypospolitej zaliczała się do najpopularniejszych publicystek i autorek żydowskich. W swej autobiografii, opublikowanej w Warszawie w 1909 r. i będącej jej literackim debiutem, przedstawiła okres swojego dzieciństwa i młodości spędzony w małym miasteczku.

Reasumując, pragnę podkreślić, że opublikowane egodokumenty bardzo dobrze wpisują się w kanon literatury wspomnieniowej Żydów polskich. Ich przetłumaczenie z różnych języków i publikacja w języku polskim, z krytycznym opracowaniem znawców zawartej w nich problematyki, jest ważna, potrzebna i powinna spotkać się z szerokim zainteresowaniem społecznym. Niewątpliwie pozwalają one polskim czytelnikom, mogącym śledzić jednostkowe i zbiorowe losy Żydów na ziemiach polskich od XVII do XX w., na głębsze poznanie i zrozumienie wielu aspektów życia społecznego Żydów, a także ich kultury i religii czy relacji z nieżydowskim otoczeniem. Stwarzają tym samym możliwość lepszego poznania i zrozumienia przeszłości - w całej złożoności i wielobarwnym kolorycie religijnym oraz narodowościowym minionej rzeczywistości, która wciąż jeszcze, w stosunkowo szerokim odbiorze społecznym, nie jest, niestety, wolna od uproszczeń, uprzedzeń i stereotypów, a nawet trudnej do zrozumienia wrogości.

\author{
Wacław Wierzbieniec \\ ORCID 0000-0001-8830-9982 \\ DOI:10.30657/pha.33.2021.23 \\ (Uniwersytet Rzeszowski) \\ e-mail: wwierzbieniec@ur.edu.pl
}

12 Beniamin R., „Płonęli gniewem”. Autobiografia młodego Żyda, tłumaczenie z języka jidysz A. Kałużna, A. Szyba, wstęp i oprac. K. Kijek, Wydawnictwo PWN, Warszawa 2021.

13 R. Fajgenberg, Dziewczęce lata. Młodość w polskim sztetlu, tłumaczenie z języka jidysz I. Stempin, wstęp i oprac. J. Nalewajko-Kulikov, Wydawnictwo PWN, Warszawa 2021. 